\title{
INCLUSIVE SCHOOLS AND URBAN SPACE DIVERSITY: UNIVERSAL DESIGN STRATEGIES IN USE
}

\author{
Mualla ERKILIÇ
}

Received: 14.12.2011, Final Text: 31.01.2012

Keywords: urban space diversity; inclusive education / schools; Universal Design.
Valuing differences in terms of celebrating 'diversity' is becoming a central theme in social life and needs to be examined to demystify its overall meaning and its considerations in an urban context.

Social diversity is a concept embedded in the idea of social 'inclusion' and means more than simply uniting diverse people but rather promoting room for differences and providing equal opportunities for diverse individuals. This paper aims to refer and exemplify the possibilities of 'urban space diversity' as a spatial formation that can be realized through Young's (1990) 'multiuse differentiation of spaces' in urban life.

The spatial peculiarities of Inclusive Education (IE) in this context will be seen as an example of 'multiuse differentiation of urban space diversity' due to its premise of providing equal opportunities to students with diverse abilities. Universal Design (UD), which seeks social inclusion through design and is based on the idea of design for diverse users, will be used as a tool to provide multiuse differentiation of the IE physical environment while promoting spaces for urban diversity.

This paper aims to discover the potential architectural means of 'multiuse differentiation of diversity of spaces' in Inclusive Educational environments with the help of the UD paradigm that emphasizes the significance of the diversity of usability while addressing (a) diversity of users, integrating students with different abilities; (b) diversity of facilities, making educational and non-educational facilities available to diverse users; (c) diversity of spaces, enriching the type and quality of spaces by providing 'flexible', 'intuitive', 'perceptible', 'accessible' as well as 'safe', 'tolerable', and 'well-dimensioned' spaces for diverse users.

It is underlined that inclusive school environments as a form of urban space diversity, differentiated and diversified by means of the principles of UD, can be considered as a catalyst for social inclusion via diversity in an urban context. 


\section{INTRODUCTION}

Valuing differences in terms of celebrating diversity in society is becoming a central theme in all sectors of life and needs to be examined so that its overall meaning can be demystified and so that its particular considerations in an urban society can be explored.

Since this paper is devoted to discussing the potential architectural reflection of urban space diversity with the example of spatial references of inclusive school environment promoting diversity and inclusion in education, it would be helpful to discuss very briefly the controversial concept of diversity and its relation to connotations of social inclusion. The conceptual relationship between social diversity and inclusion, and the concern about diversity in urban life and spaces, need to be clarified.

Since abstract ideas describing real situations can perhaps only be clarified with their particular manifestations in society this paper presents the abstract issue of urban diversity by describing a specific realization in social life. In this paper architectural formations of IE, which accommodates diverse students in its learning milieu, will be analyzed as a particular spatial representation of urban space diversity. The relationship between diversity of users and diversity of physical environment is crucial in the physical educational environment of IE. The strategies of Universal Design (usable, flexible, perceptible, accessible, safe, tolerable, affordable) that call for design for diverse users will be used as a supportive catalyst to realize an inclusive education environment as a form of urban space diversity.

Depending upon the specific underlying interests and philosophy, the concept of diversity is embedded in different discourses with various connotations in sociological, cultural, political, and administrative studies that have found resonance to varying extents in urban and architectural studies. The analytical functionalist tradition includes both descriptive and interpretative connotations of diversity. In the former case this concept is viewed as ahistorical and universal, with its normative connotations of differences among ethnicity, gender, race, age, and ability/ disability. The interpretative case views diversity as a socially constructed phenomenon -historical and contextual- where the paradoxes of differences are questioned through the diversity of symbols, languages, behaviors, actions of different groups or communities, etc.

In politics, the issue of diversity involves the constitutional principle of equality. Developments in human rights and unequal power relations in socioeconomic and political conditions of society have been considered as rights-based aspects of diversity projects. The ideas of equality, equal opportunity, freedom, democracy, and social justice as opposed to exclusion, oppression, otherness, discrimination, domination, or marginalization have become important subject matters among the social and political disciplines, including feminist, anti-racist and ethnic as well as disability studies. (Manning and Trujillo, 1996; Mohr 1996; Young, 1990, 2000; Hutchinson, 2000; Cooper, 2004; Ratcliffe, 2004; Chryssochoou, 2004). In this paper the issue of diversity is referred as a socio political concept along with its normative connotations as it has been considered in the literature of IE and UD. 


\section{CONNOTATIONS OF DIVERSITY AND INCLUSIVE SOCIETY}

In socio-political discourse against the negative impact of segregation, exclusion, and discrimination, the ideas of social integration (bring together and adapt), multiculturalism (create a sort of mosaic), inclusive society (include all), and social cohesion (hold together but not homogenously) have been introduced as some constructive strategies for valuing difference and celebrating diversity, as opposed to uniformity and assimilation (melt into the mainstream). These concepts value the coexistence of different identities, origins, and groups in society while enabling all to participate in a shared social, economic, cultural, and political life on the basis of equal rights (Young, 1990; Blum, 1996; Ratcliffe, 2004; Levitas, 2005; Johnson, 2009; Wetherel, 2009). Although some claim that diversity may lead to isolation and fragmentation in communities (Wetherel, 2009, $25)$, the positive impact of social inclusion has gained impetus among the international and national administrative units that determine and prescribe various legislation, policies, strategies, and action plans. The political strategies discussed at the World Summit for Social Development held in 1995 and The Copenhagen Declaration and Program of Action are two initiatives that found resonance in all countries. A DESA (UN Department of Economic and Social Affairs) report presents "the concept of 'social integration to create an inclusive society', 'a society for all', as one of the key goals of social development" (DESA, 2009, 6). The Declaration refers to aspects of social diversity and integration and confirms its
"commitment to promoting social integration ... based on the promotion and protection of all human rights, as well as on non-discrimination, tolerance, respect for diversity, equality of opportunity, solidarity, security, and participation of all people, including disadvantaged and vulnerable groups and persons." (DESA, 2009, 6)

In fact, social integration and social inclusion are two similar and overlapping concepts that are used interchangeably despite some differences in nuance in the sociopolitical context. In general, both ideas value differences and an inclusive society promoting the integration of all people with diverse characteristics, qualities, and abilities. Social integration can be perceived as a political consensus to achieve inclusive society by means of some rules and principles. However, social inclusion focuses on the implementation of the given political goals using multidimensional possibilities in equal opportunities. This explains the conceptual relationship between social diversity and social inclusion, which must not be understood as bringing diverse people together to melt in a pot and assimilate, but rather promotes diversity by means of equal opportunities of diverse individuals. This also means that "not all individuals and/or groups in societies are eager to be 'integrated' into mainstream society, but all strive to be included." (DESA,2009,11). In other words, unlike social integration which is provided and offered to people by means of some rules, norms and policies, social inclusion is an ultimate necessary condition achieved by people who are to be engaged only when they are given multi-dimensional equal opportunities. The idea of social inclusion emphasizes diverse individuals' full participation in all aspects of life through the recognition of their dignity; distinctive skills, abilities, and features; and individual necessities.

Social organizations and institutions (health services, education systems, etc.) that serve to include all people act as the means and mediums for the 
practical actualization of the social ideals of inclusion and diversity. In DESA it is noted that an inclusive society is

"a society that over-rides differences of race, gender, class, generation, and geography, and ensures inclusion, equality of opportunity as well as capability of all members of the society to determine an agreed set of social institutions that govern social interaction. ... It is promoted by social policies that seek to reduce inequality and create flexible and tolerant societies that embrace all people." (DESA, 2009, 8)

There is always a problem of exclusion even when tackling inclusion in society. In our society, marginalized or disadvantaged groups such as people living in poverty, persons with disabilities, children, older people, and women are often subject to exclusion. People with diverse abilities or disabilities are at risk of exclusion due to the social and physical barriers they face in everyday life. In order to create and sustain inclusive societies, legal and regulatory policy frameworks are needed to promote the protection and empowerment of these vulnerable, disadvantaged, and marginalized groups proclaiming the right to be different. Elimination of discrimination in all areas of implementation of public services including health services, education, and public and private accommodation is the practical requirement for diversity and social inclusion in society. In order to encourage that diversity or all-inclusive participation in society be mainstreamed in various areas of life, there must be equal access to public infrastructure and facilities such as information, public services (health services, education, recreation, etc.), and public spaces (schools, hospitals, libraries, cultural centers, shops etc.). In that sense inclusive schools can be accepted as one of the important institutions of social life that support inclusive society in socio-political sense.

\section{CITIES, URBAN LIFE, AND DIVERSITY}

Urban life brings together with diverse people and includes urban life services, facilities, and spaces that serve all. According to the World Urban Forum (2010), the world is inexorably becoming urban: most population growth is happening in cities and within the next few years, this growth will accelerate rapidly all around the world (UN Habitat 2010-1011). The report also points out that "based not only on moral and ethical arguments but also practical access to opportunity, the concept of an inclusive city, or city for all, encompasses the social and economic benefits of greater equality, promoting positive outcome for each and every individual in society" (UN Habitat, 2010-1011, ix). Zanoni and Janssens (2009, 3) claim that "never in the history of human kind have cities been so numerous, populated and culturally 'diverse' as today." The positive relationship between diversity and development has also been presented by urban sociologists and political scientists politics (Sennett, 1992; Sennett, 2003; Young, 1990; 1996; 2000; Wood and Landry, 2008; Reymen, 2009).

Wood and Landry (2008,10-2, 25-62) focus on diversity advantages rather than the diversity deficit in the creative power of heterogeneity and the positive impulse of intercultural exchange in the open, tolerant, and diverse milieus of cities. For Reymen (2009), in socially and economically sustainable cities, open-ended principles and conditions should underlie design policies that recognize and value differences in the achievement of inclusive cities. In the way they are designed, urban spaces can contribute to the improvement of social inclusion by allowing people to easily incorporate into and participate in urban life. Young $(1990,227)$ discusses 
the ideal city life: social relations affirming group differences and openness to unassimilated otherness without exclusion. For Young $(1990,239)$, the interfusion of groups in the city occurs partly due to the 'multiuse differentiation of social space'; for him, urban spaces are interesting due to the diversity of users and facilities they support. Actually, this situation implies that urban spaces and cities need to mediate new conceptions and social relations with the help of the multiuse differentiation of social and physical spaces.

The paper examines the possibilities of the 'multiuse differentiation of social space' as realized in urban space diversity. Its focus is given on understanding means of multiuse differentiation of urban space diversity as created by a system that supports social inclusion (Inclusive Education) as well as its institutional structure (Inclusive Education system). Inclusive school environments in architectural sense can be considered a generative form of urban space diversity. The implicit claim is that urban space diversity is only possible when it has first been demanded by social and political institutional strategies (such as inclusive education) that can be manifested in particular forms of urban space (i.e. inclusive school environment). To avoid any determinism it must be emphasized that the notion of urban space diversity not only indicates the varieties of types of urban spaces but also primarily refers to the differentiated spatial patterns that promote diversity and equal opportunities in their functioning while serving diverse users more inclusively.

\section{INCLUSIVE EDUCATION AND DIVERSE ACCESSIBILITY OF KNOWLEDGE}

The recent and developing concept of inclusive education aims to provide equal opportunities to students with diverse abilities in a shared school environment. Inclusive education at schools creates the challenge of comprehensive institutional reformations and demands adaptations in physical school environments as a form of urban space diversity. Schools are being challenged to review their curriculum, organizations, pedagogical structures in order to fulfill the requirements of inclusion.

It is evident that the idea of inclusion has developed from a long history of educational innovations. Inclusion in society and education was discussed by Dewey (1916) in the earlier part of this century as a requirement of democratic community. Following the developments achieved in human rights the ideals of inclusion have become important in different sectors of social life. For example, Friere's (1978) underlined the equality of access to education and the transformation of educational settings to accommodate all students in the society. In the field of education, research on the notion of inclusion as a response to diversity has gained momentum, particularly, in the mid-1980s; by the 1990s it had become a dominant education issue as educators confronted the constraints, problems, and efficacy of the special education system (education of students with disabilities/special needs in segregated special environments). The UNESCO Salamanca Statement and Framework for Action on Special Needs Education (1994) articulated some principles on which inclusive education is based. According to this statement students who have unique characteristics, interests, abilities, and learning needs have fundamental right to education; education system has to serve to accommodate diversity in student population; students who have a special education needs must have access to regular schools which should accommodate a child-centred pedagogy; regular schools 
with an inclusive orientation are the most effective means of combating discriminatory attitudes, creating welcoming communities, building an inclusive society and achieving for all.

The students with various disabilities, who were seen as one of the most disadvantaged groups in society, faced the problems of educational marginalization and exclusion in their learning environment. A demand for a new paradigm that would improve both the special education and existing education systems has resulted in a shift of value systems in educational institutions from segregation to inclusion. Inclusive Education begins with teaching tolerance for those who are different within one's own environment and covers a large spectrum of individual differences such as age, gender, and ability/disability as well as ethnic, cultural, linguistic, and religious background (Hick, Kershner, and Farrel, 2009; Lunt, and Norwich, 2009; Florian, 2009; Fredericson and Cline, 2009; Kugelmass, 2004). There has always been a heterogeneous group of students in the traditional schooling system, which has been organized to fulfill the needs of a wide spectrum of students. However, the traditional system is based on average standards; the system has forced all individuals to fit into the average group rather than providing services for each student's diverse needs. Similarly, even in the mainstreaming system, students with special needs still remain segregated due to the full-time placement of students with disabilities in segregated classes (Hick, Kershner, and Farrel, 2009, 2).

Generally, Inclusive Education tends to be perceived as educating students with disabilities in regular classrooms (instead of being isolated) with their so-called 'normal' peers. However, it should be conceived in a broader framework with reference to the ideals of social justice, in which meaningful social diversity can be realized with the help of social inclusion and equal opportunities. In that sense, parallel to the idea of inclusive society the close relationship between the ideas of social inclusion, equal opportunity, and inclusive education needs to be clarified in the educational context.

Within rights-based thinking in education, inclusion refers to the accessibility of education to all children, the provision of equal opportunities while recognizing diversity rather than assimilation amongst all students, and reflection on the elimination of discrimination and social exclusion. In that sense Inclusive Education has to be conceived of as a strategy or system that embraces all students with their diverse abilities and disabilities and promotes a wide level of accessibility with equal opportunities and full, active participation. A shift from the traditional education system requires various adaptations in programs, the curriculum, learning resources, and supportive services as well as appropriate spatial organization to facilitate inclusive education.

Provision of equal opportunity in inclusive education requires protection of the particularity of each student's multiple and diverse levels of capabilities. Topping and Maloney $(2005,2)$ note that the concept of equal opportunities implies treating all individuals differently (in line with their particular needs) so that they have an equal chance to achieve their full potential. Equal opportunity in this context means that each student has a right to be different and to be served differently in the education environment. In other words, individual students are equal, yet not every individual student necessarily needs the same means of access to the same knowledge. Equality must be understood here as equal access to learning but not equal access to knowledge. This indicates that inclusive education 
is possible when it is primarily based on multiple opportunities for access or diversity of accessibility of knowledge within a diverse process.

The right-based understanding of inclusion of diverse individuals in education has parallels in brain-based researches and studies. Individual differences of learning styles have also been supported theoretically by Gardner's multiple intelligence theory. This theory provides broader definition of intelligence and it places intelligence in the realm of biology and culture and has important implications for inclusive education while giving an emphasis on the diversity of abilities of learners, learning styles and learning environments (Gargiulo and Metcalf, 2010, 189; Gardner, 2006; Fleetham,2006). The Russian social theorist L. S. Vygotsky during 1920s considers the situation of the childreen with disabilities in the society and indicates the notion of positive differenciation in education where differences among students need alternative ways in education systems and he 'insists that individual differences in patterns of communication give rise to differences in patterns of social mediation and hence development' (Daniels, 2009, 33-34)

\section{DIVERSITY OF INCLUSIVE EDUCATION ENVIRONMENT AS A MULTI-USE DIFFERENTIATION OF SPACE: UNIVERSAL DESIGN STRATEGIES IN USE}

The legislation and regulations regarding the application of Inclusive Education worldwide have become clearer, especially during the1990s. The World Education Forum that was held in 2000, The Council of Europe Disability Action Plan 2006-2015, the United Nations Convention on the Rights of Persons with Disabilities 2008, and the UNESCO Policy Guidelines on Inclusion in Education 2009 all emphasized inclusive education and equal opportunities for diverse access to learning. These legislative acts created policies for an inclusive education system and raised the issue of appropriate physical environments to support inclusive education.

Inclusive education confronts and demands various organizational adaptations both in the school programming / functions and physical learning environments to be used effectively while supporting social diversity and inclusion in the society. The process of adaptations prompts not only educators but also all designers including architects to make provisions for the creation of better inclusive learning environments.

A recent approach in design, Universal Design (UD) shares the similar vision of valuing diversity with inclusive education, relies on the ideas of design for all diverse users, and underlines the issues of equality, inclusion, and social justice through design. UD originated in the USA initially following the disability movement and "the efforts of equal opportunity in education which gave way to sensitivity in design that values diversity" (Ostroff, 2001, 1-4). Mace (1998) defines UD as "the design of products and environments to be usable by 'all' people, to the greatest extent possible, without the need for adaptation or specialized design." The intent of UD is to simplify life for everyone by making products, communications, and the built environment more usable for as many and as diverse people as possible at little or no cost. UD benefits people of all ages and abilities (Mace, 1998). UD has gradually become a point of general policy agreement among various international arenas. 
One of the important design issues in UD is the issue of usability which is emphasized as a critical concept against the dominant approach of the acceptance of standard masculine forms in design activities since 1950s. With the improvement of the critical issue of usability, a broader range of human dimensions and requirements as well as the requirements of the people with disabilities are considered widely. This approach in design has its roots in the paradigm shift that has been developed in disability discourse during the 1980s. According to the social model of disability the main problem that makes people with disabilities as disabled is not the people themselves but the improper design and use of physical environments. Based on this paradigm shift, UD and its principles began to be considered along with some ethical issues of social inclusion and social diversity in order to achieve widest range of usability in the physical environments. UD includes seven principles to be integrated into the design of products, environments, and communications. The principles can be summarized briefly:

1. Equitable Use: The design is useful and marketable for people with diverse abilities.

2. Flexibility in Use: The design accommodates a wide range of individual preferences and abilities.

3. Simple and Intuitive Use: Use of the design is easy to understand, regardless of the user's experience, knowledge, language skills, or current concentration level.

4. Perceptible Information: The design communicates necessary information effectively to the user, regardless of ambient conditions or the user's sensory abilities.

5. Tolerance for Error: The design minimizes hazards and the adverse consequences of accidental or unintended actions.

6. Low Physical Effort: The design can be used efficiently and comfortably and with a minimum of fatigue.

7. Size and Space for Approach and Use: Appropriate size and space is provided for approach, reach, manipulation, and use, regardless of the user's body size, posture, or mobility (The Center for Universal Design 1997).

UD offers a design approach that supports the ideals of diversity of Inclusive Education and physical environment, which demands what Young (1990) calls the multiuse differentiation of diversity of space. Facilitating diversity in inclusive school buildings requires taking into account the following issues as multiuse differentiation of inclusive school environment:

a. Diversity of Users: broadening the range of diversity of user type with the principle of equality while integrating students with different abilities,

b. Diversity of Facilities: serving for both educational and noneducational activities of diverse users,

c. Diversity of Spaces: enriching type and quality of spaces by providing flexible, intuitive, perceptible environments available to diverse users and providing safe, well-dimensioned, comfortable spaces. 
a. Diversity of Users: Inclusive education is mainly related to the listening to the voices of the school community. Inclusion of users is about empowering all members of school community who are valued and treated with respect. Students with diverse abilities, educational staff, rehabilitation professionals, parents, caretakers, and the local community all contribute collaboratively to the diversity of inclusive school environments. When implementing inclusive education programs, it is important to clarify which type of user is going to use the school for what type of activity during and outside of school hours. Students with diverse abilities/learning styles and with/without special educational needs are integrated into general education environments. Students with diverse abilities / disabilities can be grouped in two categories (Gargiulo and Metcalf, 2010, 51-52, 88-89): (a) students with high-incidence disabilities and gifts and talents (learning disabilities, speech and language disorders, emotional and behavioral disorders, and gifts and talents); (b) students with low-incidence disabilities and other special needs (hearing and visual impairments, physical disabilities, cultural or linguistic background, and socio-economic conditions).

b. Diversity of Facilities includes both educational and non-educational facilities; includes health, social, and service facilities. In inclusive education, access to knowledge varies and requires some adaptations and changes to provide equal opportunities to diverse users. The inclusive educational activities related to curriculum require multiple resources and teaching techniques. The regular teaching program has to be tailored to address diverse learner needs. It must offer choices to match a variety of learning styles, sensory demands, background knowledge, and skills. Students must be free to choose the best way to express themselves in a flexible way (through texts, digital or tape recordings, visual, auditory, e-books, etc.). Multiple means of representations help students to feel valued, respected, and safe in their educational and social environments. Technology enhances the multiple means of representations and increases the accessibility of required knowledge for individuals with diverse needs. The educational facilities require collaboration among general education and special education teachers and learning assistants who use multiple teaching modalities in monitor process of their students. The learning spaces (classrooms, workshops etc.) are shared by two teachers (general and special) at the same period as needed. This kind of duality requires special organization in the classrooms. The rehabilitation and medical facilities, in addition to community facilities that provide services such as vocational training, music, sports and arts activities, and conferences, contribute to the diversity of inclusive schools.

c. Diversity of Spaces: Broadening the range of user types and facilities and integrating students with different abilities in inclusive schools demands multiuse differentiation of spaces in educational, social, and technical ways. Multiuse differentiation of spaces can be experienced in general design schema, functional organization, and technical arrangement of inclusive school buildings. Unlike the uniformity of traditional school organizations, in inclusive schools the diversity of building elements serves a multiplicity of users. All teaching spaces (classrooms, laboratories, etc.), common spaces (open and closed spaces for leisure activities, etc.), and service spaces (rehabilitation units, restrooms etc.) must be arranged in a way that meets the various needs of students of diverse abilities. 
As UD strategies suggest, the use of these spaces must be equitable, usable, and accessible for their users. The spaces must provide equal opportunities and diverse means of use for all users. This means that all spaces need to make private and public space equally available for all students according to their demands. Apart from the first principle of equality, the remaining UD principles are related to special aspects of inclusive environment and can be summarized in three categories as follows:

i. Provide a Diversity of Spaces with flexibility / adaptability / mobility / accessibility.

- Flexible classroom layout can accommodate a variety of different learning spaces for a variety of functions, and they must be capable of changing as required.

- Adaptable spaces can accommodate private or group study activities by using moveable, acoustic partition walls and sliding doors between two teaching and / or circulation spaces that can provide the opportunity to expand, combine, or divide spaces for diverse facilities. For example, flexible learning spaces with two teachers must allow different study options. Learning facilities can extend to outdoor spaces.

- Accessible and adaptable spaces allow easy movement of users with diverse needs with wheelchairs, walking aids, or heavy bags.

- Creating mobile and adaptable seating arrangements that can be easily repositioned contributes to efficiency in learning and saves time during alternative teaching situations for individual and group work.

- The overall schema of an inclusive school building should provide adaptable and flexible arrangements for rehabilitation or health care units that are easily accessible from common and learning spaces.

- The service spaces such as parent or caretaker rooms must be taken into consideration in the flexible arrangement of educational and non-educational spaces.

- In order to achieve sustainable solutions, spatial arrangements can be developed using the ideas of all participating users.

ii. Provide Diversity of Spaces with simplicity / intuitiveness / clarity / perceptible understanding.

- Students may have varying learning processes depending on their cognitive skills. An easy-to-understand organization between spaces is required. If the layout is confusing, students with emotional and behavioral disorders will feel anxious, or students with visual impairments will find it hard to orient themselves. The provision of different modes of representation (pictorial, verbal, tactile) is necessary in both educational and non-educational facilities.

- Spaces should provide essential information in the most legible forms possible. Well-defined routes for orienting users sharing the same spaces will be necessary for encouraging communication and social interaction (corridors that open to/intersect at a central space).

- A general plan layout that allows the use of perceptible information through design of signs, landmarks, and application of colors and textures can enable users to find their way. 


\section{iii. Provide Diversity of Spaces with wide range of capabilities / wide range of size and space requirements / comfort and safety.}

- Spaces as well as the equipment of the spaces must allow students with diverse capabilities to maintain their neutral body position. During the use of spaces and equipment, minimization of sustained physical effort and repetitive actions encourages all users with different abilities.

- Appropriate size and spaces in educational and non-educational spaces provide easy approach and manipulation for all users. A clear line of sight, adequate spaces for use of assistive devices, and accommodation of variations in use of elements like doors, door handles, and service spaces are important in serving diverse users.

- Arrangement of the spaces and equipment to minimize hazards and errors and provide warnings and safe features is important to prevent accidents.

- The varying degrees of visual capacities require different levels of lighting. Flexible and adaptable levels of lighting, color, and contrast of objects can be used to overcome these conflicting needs and serve a diversity of needs.

- Noise can be controlled through acoustic design (with materials and flexible partitions) by considering the needs of students with varying levels of hearing, sensory and visual impairment, and diverse learning styles (especially auditory learners).

- Technology integrated spaces are needed in schools to support students' learning by maximizing their physical, cognitive, and sensory capabilities.

\section{CONCLUSION}

The architectural environment of Inclusive Education that provides equal opportunities while accommodating diverse students in its learning milieu can be perceived as a particular form or representation of multiuse differentiation of urban space diversity. The strategies of Universal Design summarized above give an idea of the possibilities of differentiation of spaces that promote diversity of usability in an educational environment seeking inclusion and diversity. Universal Design principles can be seen as a supportive catalyst for the spatial realization of inclusive school buildings and their environments.

\section{REFERENCES}

BLUM, L. (1996) Antiracism, Multiculturalism, and Interracial Community, eds. R.C. Manning, R. Trujillo, Social Justice in a Diverse Society, Mayfield Publishing Company, USA; 370-93.

CHRYSSOCHOOU, X. (2004) Cultural Diversity, Blackwell Publishing, UK.

COOPER, D. (2004) Challenging Diversity: Rethinking Equality and the Value of Difference, Cambridge University Press, UK

DANIEL, H., (2009) Vygotsky and Inclusion, eds. P. Hick, R. Kershner and P.T. Farrel., Psychology for Education, Routledge: Taylor and Francis Group, UK; 24-37. 
DESA (2009) United Nations Department of Economic and Social Affairs, Report Creating an Inclusive Society: Practical Strategies to Promote Social Integration, http://www.un.org/esa/socdev/egms/docs/ 2009/Ghana/inclusive-society.pdf, retrieved 30.05.2011.

DEWEY (1916) Democracy and Education, Macmillan, New York.

FLORIAN, L. (2009) Towards an Inclusive Pedagogy, eds. P. Hick, R. Kershner, P.T. Farrel, Psychology for Inclusive Education, Routledge, Taylor and Francis Group, UK; 38-51.

FLEETHAM, M. (2007) Multiple Intelligences in Practice, Network Continuum Education Press, UK.

FREDERICSON, N., CLINE, T. (2009) Special Educational Needs Inclusion and Diversity, Open University Press, USA.

FREIRE, P. (1978) Pedagogy in Process, http:/ / education.stateuniversity. com/pages/1998/Freire-Paulo-1921-1997.html, retrieved 27.01.2012.

GARDNER, H., (2006) The Development and Education of Mind: Selected works of Howard Gardner, Routledge, UK.

GARGIULO, R., M., METCALF, D. (2010) Teaching in Today's Inclusive Classrooms, Wadsworth Cengage Learning, USA.

HICK, P., KERSHNER, R., FARREL, P.T. (2009) Introduction, eds. P. Hick, R. Kershner, P.T. Farrel, Psychology for Inclusive Education, Routledge, Taylor and Francis Group, UK; 2.

HUTCHINSON, J. (2000) Urban Policy and Social Exclusion, eds, J.P. Simith, Policy Resposes to Social Exclusion, Open University Press, Maidenhead, Philadelphia.

JOHNSON, N. (2009) Building an Integrated Society, eds. M. Wetherel, M. Lafleche, R. Berkeley, Identitiy, Ethnic Diversity and Community Cohesion, Sage Publication, UK; 24-33.

KUGELMASS, W.J. (2004) The Inclusive School: Sustaining Equity and Standards, Teachers Collage Press, UK.

LEVITAS, R. (2005) The Inclusive Society: Social Exclusion and New Labour, Palgrave Macmillan Publication, USA.

LUNT, I., NORWICH, B. (2009) Inclusive and Effective Schools, eds. P. Hick, R. Kershner, P.T. Farrel, Psychology for Inclusive Education, Routledge, Taylor and Francis Group, UK; 96-109.

MACE, R. L. (1998) A Perspective on Universal Design, presentation at Designing for 21st Century: An International Conference on Universal Design, June 1998, Hofstra University, Hempstead, New York. http: / / www.ncsu.edu/www/ncsu/design/sod5/cud/about us/ usronmacespeech.htm retrieved 04.2011.

MANNING, R.C., TRUJILLO, R. (1996) Social Justice in a Diverse Society, Mayfield Publishing Company, USA.

MOHR, D. R. (1996) Invisible Minorities, Civic Rights, Democracy, eds. R.C. Manning, R. Trujillo, Social Justice in a Diverse Society, Mayfield Publishing Company, USA; 181-5.

Ostroff, E. (2001) Universal Design: The New Paradigm, eds. W.F.E. Preiser and E. Ostroff, Universal Design Handbook, New York, McGrawHill; 1.3-1.11. 
RATCLIFFE, P. (2004)'Race', Ethnicity and Difference: Imagining the Inclusive Society, Open University Press, UK.

REYMEN, D. (2009) Coordinating Diversities for Prospering DiverCities, eds. M. Janssens, D. Pinelli, D. Reymen, S. Wallman, Sustainable Cities: Diversity, Economic Growth and Social Cohesion, Edward Elgar Publication, USA; 193-8.

SENNETT, R. (1992) The Conscience of the Eye: The Design and Social Life of Cities, W.W. Norton, New York.

SENNETT, R. (2003) Respect in a World of Inequality, W.W Norton, New York.

THE CENTER FOR UNIVERSAL DESIGN (1997) The Principles of Universal Design, Version 2.0.Raleigh, NC, NCSU, www.ncsu.edu/ www/ncsu/design/sod5/cud/. retrieved 05.2011.

TOPPING, K. and MALONEY, S. (2005) Introduction, eds. K. Topping, and S. Maloney, The Routledge Falmer Reader in Inclusive Education. London and New York: Routledge; 2-14.

UN Habitat. (2010-2011) The 2010/11 State of the World's Cities Report, "Bridging the Urban Divide", Earthscan Publishing, UK.

UNESCO Salamanca Statement and Framework for Action on Special Needs Education (1994) http:/ / www.unesco.org/education/pdf/ SALAMA E.PDF

YOUNG, I. M. (1990) Justice and the Politics of Difference, Princeton University Press, USA.

YOUNG, I. M. (2000) Inclusion and Democracy, Oxford University Press, New York.

YOUNG, I. M. (1996) Social Movements and Politics of Difference, eds. R.C. Manning, R. Trujillo, Social Justice in a Diverse Society, Mayfield Publishing Company, USA; 445-468.

WETHEREL, M. (2009) Community Cohesion and Identity Dynamics: Dilemmas and Chellenges, eds. M. Wetherel, M. Lafleche, R. Berkeley, Identitiy, Ethnic Diversity and Community Cohesion, Sage Publication, UK; 1-14.

WOOD, P. and LANDRY, C. (2008) The Intercultural City: Planning for Diversity Advantage, Earthscan Publication, UK.

ZANONI, P., JANSSENS, M. (2009) Sustainable DiverCities, eds. M. Janssens, D. Pinelli, D. Reymen, S. Wallman, Sustainable Cities: Diversity, Economic Growth and Social Cohesion, Edward Elgar Publication, USA; 3-25. 
Alındı: 14.12.2011, Son Metin: 31.01.2012

Anahtar Sözcükler: kentsel mekan farklılaşması; kaynaştırma eğitimi ve okulları; evrensel Tasarım.

\section{KAYNAŞTIRMA EĞİTIMİ OKULLARI VE KENTSEL MEKAN FARKLILAŞMASI: EVRENSEL TASARIM STRATEJISİ AÇISINDAN BİR DEĞERLENDİRME}

Sosyal ve kentsel yaşamda 'farklı' olmayı 'çeşitli'liğin gücü olarak algılamak ve övmek önem kazanan bir yaklaşım olarak karşımıza çıkmaktadır. Sosyal 'kaynaşma' farklı olan bireyleri salt birarada tutma misyonunun ötesinde farklı bireylere sağlanacak fırsat eşitliği ile bu farklılığın / çeşitliliğin korunarak birlikte olmanın önemini vurgular. Bu makale kentsel mekan farklılığı konusunu Young'ın (1990) kentsel yaşamdaki 'çoğulcu mekan farklılaşması' kavramına referans vererek bir örnek sosyal kentsel mekan üzerinden tartışmayı amaçlamaktadır.

Kaynaştırma eğitiminin sürdürüldüğü eğitim mekanları farklı kapasite ve özellikteki öğrencileri bir araya getirme amacını güderken çoğulcu kentsel mekan farklılaşması için bir örnek teşkil eder. 'Evrensel Tasarım' ise ayırım gözetmeden 'farklı' bireylerin gereksinimlerini ön plana çıaran mimari anlayışı ile kaynaştırma eğitimi yaklaşımı destekler niteliktedir.

Makale Evrensel Tasarım prensiplerine dayanarak kaynaştırma eğitim mekanlarının çoğulcu ve farklılaşan mekansal özelliklerini a) farklı kullanıcı grubu b) farklı işlevsellik, c)farklı mekansal özelliklerini vurgularken evrensel tasarımın eşitlik, duyarlılık, algılanabilirlik, erişilebilirlik, emniyetlilik gibi temalarını öne çıkaran bir mekansal değerlendirme yapar.

Tartışmada kaynaştırma eğitimi mekanlarının birer kentsel mekan farklılaşması modeli olduğu ve bu mekanların oluşturulmasına Evrensel Tasarım prensiplerinin bir katalizör olarak katkı sağlayabileceği vurgulanmaktadir.

MUALLA ERKILIÇ; B. Arch., M.Arch., Ph.D.

Received B. Arch. and M. Arch. degrees from METU Department of Architecture, Ankara, Turkey and Ph.D. Degree from University of Edinburgh, Department of Architecture, UK (1994). Currently teaching on architectural design and universal design at METU, Department of Architecture. Fields of interest are architectural theory and criticism, architectural education, architectural practice, and universal design. 